\title{
The southern churchill, Petrocephalus wesselsi, a new species of mormyrid from South Africa defined by electric organ discharges, genetics, and morphology
}

\author{
Bernd Kramer ${ }^{\mathrm{a}} \&$ F. Herman van der Bank ${ }^{\mathrm{b}}$ \\ ${ }^{a}$ Zoological Institute of the University, D-93040 Regensburg, Germany \\ (e-mail: bernd.kramer@biologie.uni-regensburg.de) \\ ${ }^{\mathrm{b}}$ Department of Zoology, Rand Afrikaans University, P.O. Box 524, Auckland Park, 2006, South Africa
}

Received 28 March $2000 \quad$ Accepted 7 August 2000

Key words: Petrocephalus catostoma, allopatric speciation, Upper Zambezi, Limpopo, Incomati, Pongola, Mormyridae

\begin{abstract}
Synopsis
East African and south African churchills (Petrocephalus, Mormyridae) were synonymised in 1959 to become members of a single species of subcontinental, southern African distribution, Petrocephalus catostoma (Günther, 1866). By comparison with the type material for $P$. catostoma from the Ruvuma River and $P$. stuhlmanni from the Ruvu River, both of East African origin, we confirm the South African form of churchill to represent a new species, $P$. wesselsi, ranging from the northern Limpopo and Incomati systems south to the Pongola River (Natal) as its southern limit. We also compared churchills from the Sabie River ( $25^{\circ} \mathrm{S}$, South Africa, Incomati system) with churchills from the Upper Zambezi River ( $17^{\circ} \mathrm{S}$, Namibia), using electric organ discharges (EODs) and morphology. The duration of an EOD pulse of the South African form $(N=39 ; 943.2 \pm$ S.E. $18.82 \mu \mathrm{s})$ is, on average, more than twice that of the Upper Zambezi form $(N=37 ; 436.6 \pm 15.1 \mu \mathrm{s})$, and the amplitude of the second head-positive phase $(\mathrm{P} 2$ phase relative to $\mathrm{P} 1=1)$ significantly weaker $(0.133 \pm 0.0005$ vs. $0.472 \pm 0.002$ for Upper Zambezi males, $0.363 \pm 0.03$ for Upper Zambezi females). In contrast to the Upper Zambezi form, the EOD of the South African form exhibits no difference between the sexes. Fish from the two origins differ significantly in 11 out of 14 anatomical characters studied, confirming molecular genetic differentiation on the species level.
\end{abstract}

\section{Introduction}

Traditionally, zoologists have derived all information on phylogeny from morphometrics; molecular genetic data sets are now widely regarded as equally informative and have revolutionized the field (e.g., Kocher \& Stepien 1997). A further revolution is brought about by a new consideration for specific behavioural traits, as most clearly exemplified by the 'recognition concept' of speciation. The 'recognition concept' of speciation emphasizes adaptations in biparental organisms involving signalling between mating partners; together these adaptations form the 'specific-mate recognition system’ (e.g., Paterson, 1978, 1988, Paterson in McEvey
1993). The key significance of this concept, as compared to the traditional biological species concept, is also recognized for African freshwater fishes (Ribbink 1994). Taxonomic analyses considering mating signals will substantially gain in resolving power and yield more reliable results than those that limit themselves to anatomical and genetic characters, especially among closely related fishes.

While conducting an analysis of electric organ discharges (EOD) on mormyrids from South Africa, usually regarded as $P$. catostoma, specimens from the Sabie River (Figure 1a) emitted a distinctively different EOD compared to $P$. catostoma specimens from the Upper Zambezi system (Namibia, Figure 1b). The differences 

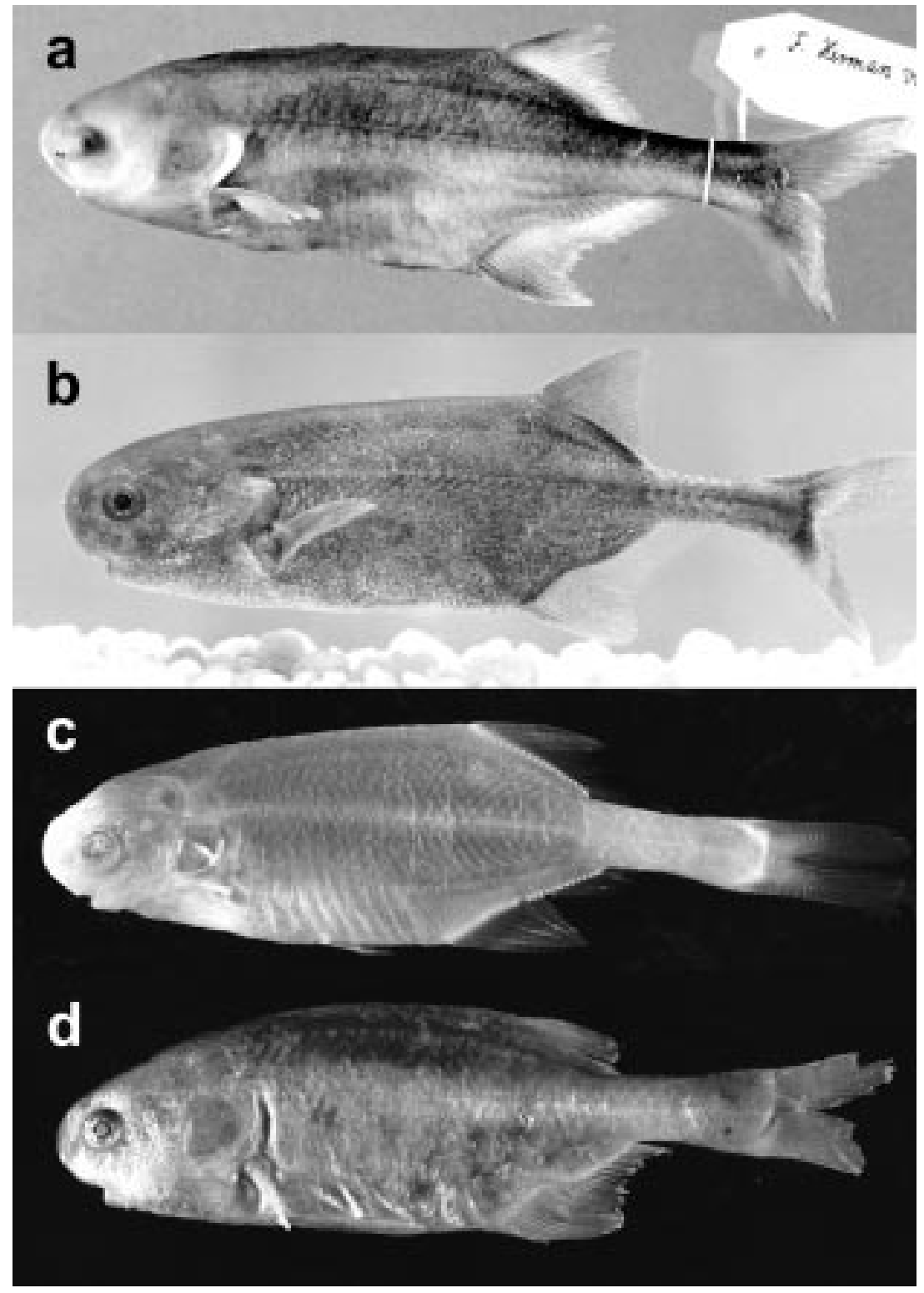

Figure 1. a - Photographs of Petrocephalus wesselsi (holotype, $11.4 \mathrm{~cm}$ SL; fixed fish) from the Sabie and b - P. catostoma (fish photographed alive, $7.9 \mathrm{~cm} \mathrm{SL}$ ) from the Upper Zambezi rivers. c - The lectotype $(4.91 \mathrm{~cm} \mathrm{SL})$ of $P$. catostoma from the Ruvuma River. $\mathrm{d}$ - The holotype of $P$. stuhlmanni $(8 \mathrm{~cm} \mathrm{SL}$ ) from the Kingani (Ruvu) River.

in EOD supported Van der Bank's (1996) suggestion of a species difference based on molecular genetic results.

Petrocephalus Marcusen, 1854 is a diverse genus that includes approximately 20 species found throughout tropical Africa. In southern Africa only one species is recognized (Gosse 1984, Bell-Cross \& Minshull 1988). More recent work (Skelton 1993) again recognized a single species of Petrocephalus, but stated a critical comparison of taxonomic characters from different populations had not been accomplished.

The first South African record is that of a single specimen from Leydsdorp (Northern Province, Limpopo system) that Gilchrist \& Thompson (1913, p. 326) referred to as $P$. stuhlmanni Boulenger. This species 
was synonymised with $P$. catostoma by Whitehead \& Greenwood (1959) although specimens from South Africa have not been examined. Since then, specimens from South Africa have routinely been regarded as P. catostoma (Günther, 1866), known commonly as the churchill. It is a wide ranging species reported from the Victoria Nile southward to the lower Pongola River in KwaZulu-Natal (latitude $27^{\circ} \mathrm{S}$ ).

EOD are a communication and location signal in mormyrid fishes (reviews, Bastian 1990, 1994, Moller 1995, Kramer 1990, 1994, 1996). EOD play a key role in pair formation and mating in Pollimyrus isidori (today, recognized as $P$. adspersus; Bratton \& Kramer 1989, Crawford 1991), and social attraction in Campylomormyrus rhynchophorus (Kramer \& Kuhn 1993). EOD of sympatric mormyrids of the Upper Zambezi are species-specific and have been used for phylogenetic analysis (Van der Bank \& Kramer 1996). It is our intent to utilize EOD as a taxonomic tool in distinguishing species, in addition to anatomical and genetic data, and is utilized here as a characteristic in systematic analysis.

\section{Material and methods}

Measurements used to establish morphometrics follow Figure 2 and were made using vernier calliper readings to $0.1 \mathrm{~mm}$. Abbreviations: PDL = predorsal length: distance tip of snout - dorsal fin origin, $\mathrm{PAL}=$ distance tip of snout - anal fin origin, LD = dorsal fin length, $\mathrm{LA}=$ anal fin length, $\mathrm{pD}=$ distance dorsal fin origin - end of caudal peduncle, CPL $=$ length of caudal peduncle, $\mathrm{CPD}=$ depth of caudal peduncle: the least vertical distance across the caudal peduncle, $\mathrm{LS}=$ length of snout: distance tip of snout - centre of eye,
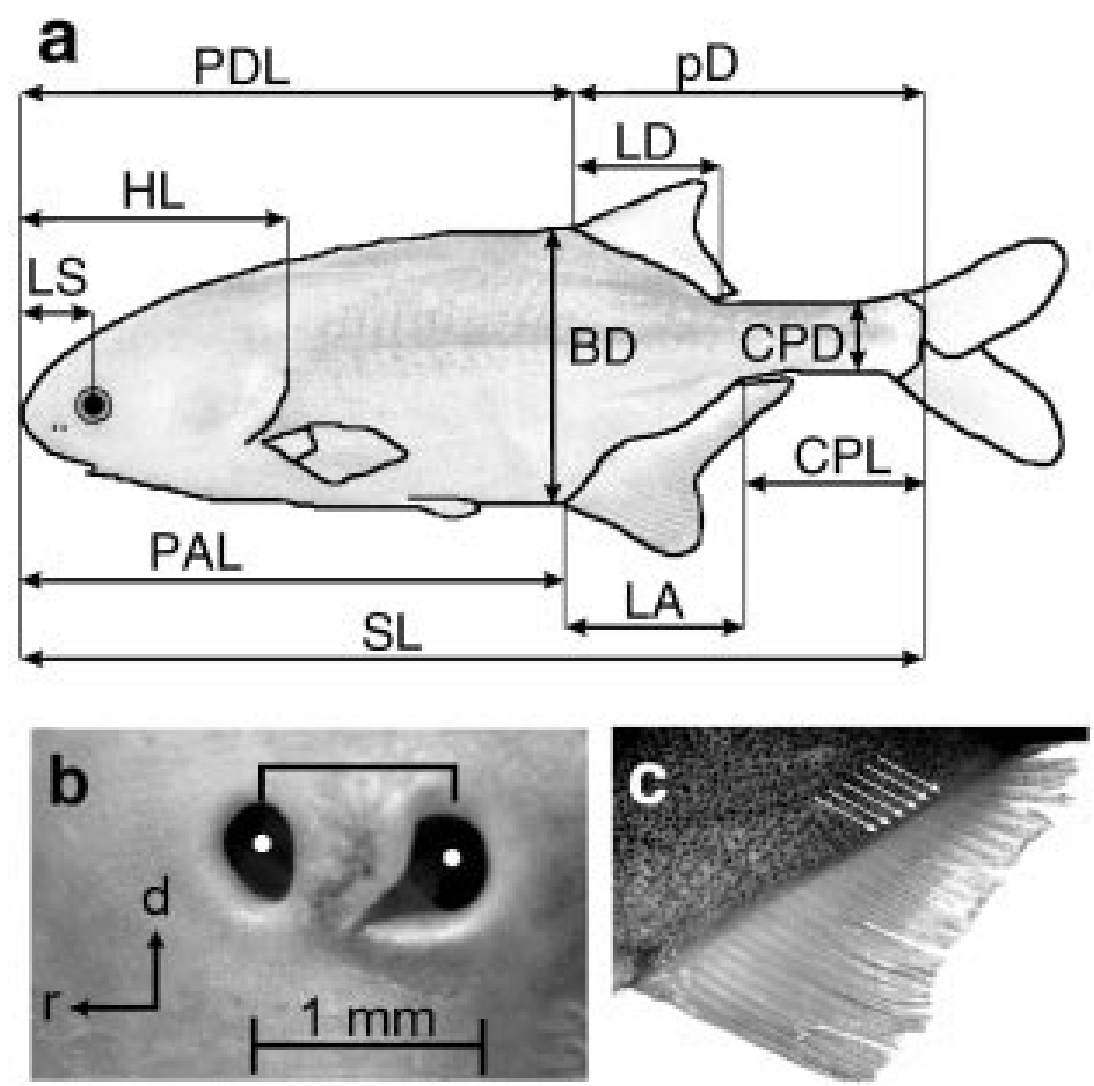

Figure 2. a - Morphological measures used in the present study (for explanations, see Material and methods). b - Distance between nares, from centre to centre (white points, shown on a P. catostoma, $\mathrm{r}=$ rostral, $\mathrm{d}=\mathrm{dorsal}$ ). $\mathrm{c}-$ Fin rays, counted at the base of the fin (fin shown here is anal fin of a $P$. catostoma). Arrows indicating a few rays. 
$\mathrm{HL}=$ head length: distance tip of the snout - furthest bony edge of the operculum, $\mathrm{Na}=$ distance between the pair of nares of one side (from centre to centre), $\mathrm{SL}=$ standard length: distance tip of the snout - midbase caudal fin, $\mathrm{BD}=$ body depth: the greatest vertical distance across the body, $\mathrm{nD}=$ number of dorsal fin rays, $\mathrm{nA}=$ number of anal fin rays, $\mathrm{SPc}=$ number of scales around caudal peduncle. Abbreviations used to represent institutions and collections follow Leviton et al. (1985).

Most scale counts are not considered here as they are subcutaneous in Petrocephalus and many other mormyrids, and it is almost impossible to gather an objective count without having to clear and counterstain specimens. It is considered very impractical and has similarly been avoided in previous systematic research. Similarly, lateral line pores were not considered as they are not visible.

Specimens studied were initially identified using dichotomous keys in Bell-Cross \& Minshull (1988) and Skelton (1993), which are considered effective for fish populations occurring in South Africa and Namibia.

Excluding three fish from Zambezi, electric organ discharges of each fish were recorded in the field immediately after capture, using a 37-1 plastic aquarium filled with river water where the fish was collected. Conductivity changes possibly affecting EOD were excluded (Bell et al. 1976, Bratton \& Kramer 1988, Kramer \& Kuhn 1993).

Temperature $\left( \pm 0.1^{\circ} \mathrm{C}\right)$ and water conductivity $\left( \pm 1 \mu \mathrm{S} \mathrm{cm}^{-1}\right)$ were constantly monitored using an electronic meter (LF92 by WTW, Germany). Fish were placed between a pair of carbon rod electrodes that was connected to a differential amplifier with a variable gain (up to $\times 10 ; 0.2 \mathrm{~Hz} \ldots 100 \mathrm{kHz}$; filter slopes, $-3 \mathrm{~dB}$ per octave; electronics workshop, Biology Department, University of Regensburg). Amplifier output was recorded by a digital storage oscilloscope (up to $10 \mathrm{MHz}$ conversion rate; amplitude resolution, 8 bit; 512 points per trace), and data were numerically transferred onto the hard disk of a computer via digital interface. Usually 8 traces per fish were recorded. Equipment was battery-operated.

For analysis of EOD waveforms custom-designed computer programs were used (programmed using a software package for signal analysis, Famos v3). When necessary, EOD duration was corrected for $25^{\circ} \mathrm{C}$ using a $\mathrm{Q}_{10}$ value of 1.5 (Kramer \& Westby 1985) before data analysis. Fourier analysis was performed using a routine provided by Famos v3.
Subsequent to EOD recording fish were killed by an overdose of the anaesthetic 2-phenoxy-ethanol, their standard length determined, and fixed in $10 \%$ formalin for morphological studies. Fish were sexed using (1) the kink criterion of the anal fin base for orientation (kink absent in females), (2) dissection of the gonad, and/or (3) histology of the gonad (which was the decisive criterion in case of conflict). Paraffin-embedded $7 \mu \mathrm{m}$ slices of the gonads were stained with Azan (Romeis 1989). Statistical analyses were carried out as indicated in Results; $p$ values are two-tailed unless otherwise stated. Computer programs used were Prism v2.01 and StatView v5.

\section{Comparative material}

Forty specimens of Petrocephalus catostoma from the Upper Zambezi River System, East Caprivi, Namibia (Figure 3), totalling at least 13 males and at least 12 females in size range $28-105 \mathrm{~mm}$ SL with a smallest gravid female $97 \mathrm{~mm}$ SL. Of these, 35 specimens were sampled at Katima Mulilo, among rocks in the middle of the river (opposite boat landing), $17^{\circ} 29^{\prime} \mathrm{S}, 24^{\circ} 18^{\prime} \mathrm{E}$, 10 September 1993 , at water conductivity and temperature: $81 \mu \mathrm{S} \mathrm{cm}^{-1}, 21.8^{\circ} \mathrm{C}$, no gravid female, SMF 28265 (27 specimens); 3 specimens from same location, 9 August 1994, SL from 77-95 mm SL, all female (presently alive in captivity); 1 specimen from Lisikili backwater, $17^{\circ} 29^{\prime} \mathrm{S}, 24^{\circ} 26^{\prime}$ E, 6 March 1994, water conductivity and temperature: $56.1 \mu \mathrm{S} \mathrm{cm}^{-1}, 26.8^{\circ} \mathrm{C}$, gravid female $105 \mathrm{~mm} \mathrm{SL}$; 1 specimen from Kwando River, Nakatwa, $18^{\circ} 06^{\prime}$ S, $23^{\circ} 23^{\prime}$ E, 9 March 1994, water conductivity and temperature: $130 \mu \mathrm{S} \mathrm{cm}^{-1}$, $24.9^{\circ} \mathrm{C}$, gravid female $97 \mathrm{~mm}$ SL.

Five specimens of $P$. catostoma from the Ruvuma River, representing the lectotype (183.10.12:4) and four paratypes $(183.10 .12: 5-6)$ stored in the Natural History Museum (London), collected by Livingstone in 1863 , were included in this study as comparative material (size range $42-49 \mathrm{~mm}$ SL). The single existing specimen of P. stuhlmanni Boulenger, 1909 was also included as comparative material. This specimen from the Kingani (Ruvu) River in Tanzania represents the holotype (1907.12.3:1) for this species that has been synonymised with $P$. catostoma by Whitehead \& Greenwood (1959). It is stored in the Natural History Museum, London.

$P$. catostoma was first recorded from the Upper Zambezi (Lialui or Lealui, Barotseland, present-day Zambia) by Gilchrist \& Thompson (1917, p. 562) referring to their species description of $P$. catostoma 


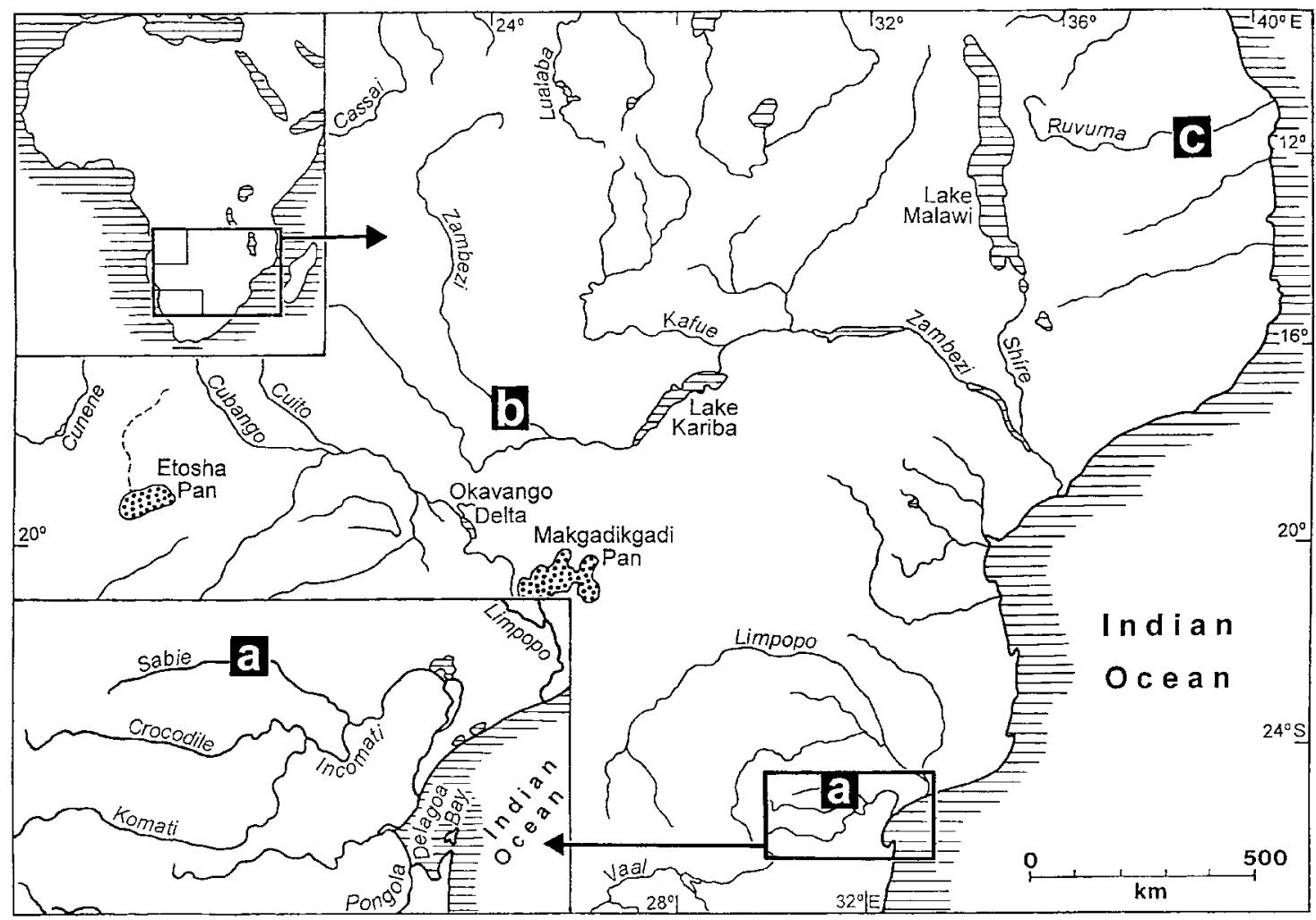

Figure 3. Partial map of southern Africa showing the type locality of the new species, $P$. wesselsi $(\mathrm{a}=$ Sabie River $)$, the sampling locality of comparative material of $P$. catostoma $(\mathrm{b}=\mathrm{Upper}$ Zambezi River), and the type locality for $P$. catostoma $(\mathrm{c}=$ Ruvuma River). Enlarged lower left: map of the type locality of the new species, $P$. wesselsi (a, close to Skukuza, Kruger National Park).

specimens from the 'Kafue River, Upper Zambezi' in Gilchrist \& Thompson (1913, p. 325). (Today we consider the Kafue River part of the Middle Zambezi system that begins below the Victoria Falls.) Barnard (1948) confirmed the presence of P. catostoma for the Upper Zambezi/Okavango system but followed Boulenger (1909) in listing this species under the name P. stuhlmanni. Barnard (1948) could not resolve the discrepancy between Boulenger on one hand, and Gilchrist \& Thompson on the other. Jubb (1958) reported nine other specimens of $P$. stuhlmanni from the Upper Zambezi, shortly before $P$. stuhlmanni was synonymised with $P$. catostoma by Whitehead \& Greenwood (1959). Since then all authors have recognized $P$. catostoma as the only Petrocephalus species present in the Okavango/Zambezi system, except Poll (1967) and Ladiges (1964) who did not cite Whitehead \& Greenwood (1959). Poll (1967) and Ladiges (1964) instead followed Pellegrin (1936) who listed P. simus Sauvage, 1878 'for the species which we recognize as P. catostoma' (Skelton et al. 1985). P. simus was originally described from the Ogôoué River (Sauvage 1880) and occurs from Liberia to Angola (Poll 1967). However, Gosse (1984) indicates a more restricted distribution ('from Liberia to Zaïre') that excludes $P$. simus for the Okavango/Upper Zambezi system. Ladiges (1964) does not give the source of his evidence for the presence of $P$. simus in the Okavango/Upper Zambezi system, nor any taxonomical or geographical detail, and Poll (1967) refers to Pellegrin (1936) and an unpublished check-list of fish species as evidence in this regard. Neither paper is an original document for the presence of $P$. simus in the Okavango/Zambezi system. Pellegrin (1936) lists four specimens of $P$. simus from the Cubango (63-90 $\mathrm{mm} \mathrm{TL}$ ) without giving any further morphological or other detail. There is no mention of $P$. catostoma/stuhlmanni and the earlier literature relevant to these.

$P$. simus differs in coloration, maximum size, number of teeth, modal number of dorsal and anal fin rays, and scales in lateral series (as characterized by Lévêque \& Paugy 1984, Blache 1964) from P. catostoma (as 
characterized by Bell-Cross \& Minshull 1988, Skelton 1993). P. simus carries a distinctive black band that extends downward from the origin of the dorsal fin whose first few rays, as well as the external rays of the caudal fin and its base, are also black. No such black marks are found in $P$. catostoma (including all fish of the present study). $\mathrm{nD}(\mathrm{nA})$ is $22-27$ (27-33) compared to only 19-24 (25-30), the number of upper jaw teeth is $6-10$ compared to $12-16$, and the maximum size is only $90 \mathrm{~mm}$ in $P$. simus compared to $130 \mathrm{~mm}$ in $P$. catostoma, respectively.

Poll (1967: figure 7) depicts $P$. simus without any black marks, and some characters of the 4-8 individuals (of unspecified origin, p. 45) differ considerably from the definition as given by Lévêque \& Paugy (1984). For example, the number of teeth in the upper jaw (12-16) is identical to that of $P$. catostoma, but higher than that of $P$. simus; similar for the lower jaw (16-25).

In conclusion, especially for $\mathrm{nD}, \mathrm{nA}$, coloration and maximum size (which is beyond that recorded for $P$. simus, Table 2), our fish from the Upper Zambezi clearly fall within the $P$. catostoma (and not $P$. simus) definition, as summarized by Bell-Cross \& Minshull (1988) and Skelton (1993). Not a single record of $P$. simus is clearly substantiating the presence of this species in the Upper Zambezi system.

\section{Petrocephalus wesselsi, sp. nov. \\ Figures 1-8, \\ Tables 1-4}

Material examined. - 39 specimens from the Sabie River, Kruger National Park, South Africa (Figure 3), bridge near Lower Sabie tourist camp, $25^{\circ} 07^{\prime} \mathrm{S}$, 31 $1^{\circ} 5^{\prime}$ E, 29-30 March 1996, water conductivity and temperature: $139 \mu \mathrm{S} \mathrm{cm}^{-1}, 25.1^{\circ} \mathrm{C}$, totalling 20 males, 19 females, size range 59-114 mm SL, largest male $114 \mathrm{~mm}$, largest female $109 \mathrm{~mm}$, no gravid material

Holotype. - ZSM 28556, $114 \mathrm{~mm}$ SL (109 mm in 70\% alcohol), male, 29 March 1996, collection data: as given in preceding paragraph. Coll. B. Kramer and F. H. van der Bank.

Paratypes. - RUSI 54449, 13 specimens, at least 2 male, at least 5 female, size range 59-91 mm SL, collection data: same as holotype; SMF 28266, 13 specimens, at least 3 male, at least 5 female, size range 61-96 mm SL, collection data: see above; ZSM 28554, female, $81 \mathrm{~mm}$ SL; ZSM 28555, female, $69 \mathrm{~mm} \mathrm{SL}$; ZSM 28557, female, 109 mm SL; ZSM 28558, male,
$86 \mathrm{~mm}$ SL; ZSM 28559, female, $82 \mathrm{~mm}$ SL; ZSM 28560, 64 mm SL; ZSM 28561, male, 67 mm SL; ZSM 28562, $60 \mathrm{~mm}$ SL; ZSM 28563, female, $67 \mathrm{~mm}$ SL; ZSM 28564, $61 \mathrm{~mm}$ SL; ZSM 28565, female, $64 \mathrm{~mm}$ SL; ZSM 28566, 66 mm SL.

Diagnosis. - Usually $20(18-21) \mathrm{nD}, 26(25-28) \mathrm{nA}$; usually 16 (15-16) SPc; pD (2.37-2.54-2.72), CPL (4.3-4.78-5.38), HL (3.17-3.32-3.5), LD (6.4-7-7.85), LA (4.95-5.4-6), CPD (4.59-5.1-5.75), BD (3.1-3.383.79), PDL (1.67-1.72-1.77) and LS (11.1-12.3-14.5) times included in SL; long duration of EOD (644-943$1172 \mu$ s at $25^{\circ} \mathrm{C}$ ), amplitude of second head-positive peak of EOD, P2, weak (6-13.2-20\%) compared to first head-positive peak, P1 (definitions, Figure 4).

Description. - The head is broadly rounded with a small ventrally positioned subterminal mouth, situated ventral to the eye; head and body dorsolaterally compressed. Dorsal fin (a) situated about three fourths of standard length from snout, (b) obliquely oriented with anteriorly higher and posteriorly lower, (c) distal margin sharply crescentic with anterior two or three rays about 5 times longer than posterior rays together forming a point, and (d) number of rays $18(N=4), 19$ $(N=9), 20(N=21), 21(N=5)$. Anal fin (a) directly opposite to dorsal fin and obliquely oriented,

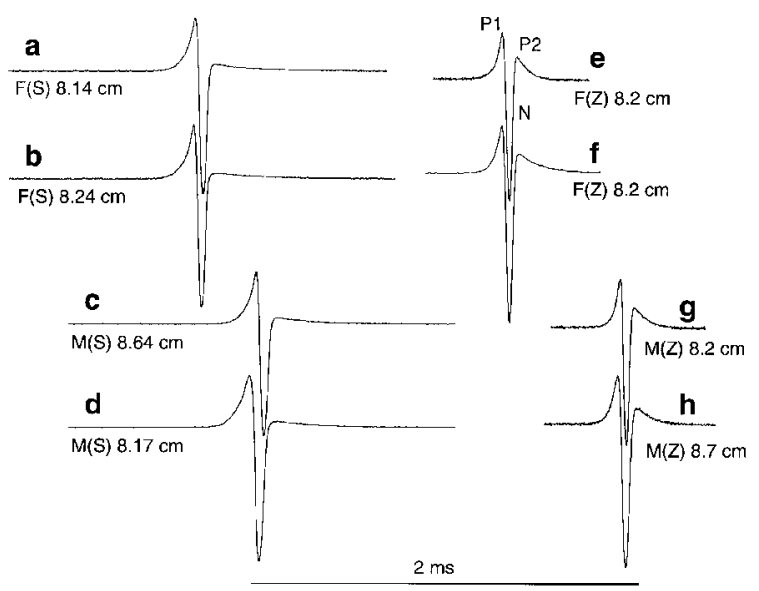

Figure 4. Waveforms of electric organ discharges for the two allopatric species of Petrocephalus. a-d, fish from the Sabie River; e-h, from the Zambezi $(\mathrm{F}=$ female; $\mathrm{M}=$ male; $(\mathrm{S})=$ Sabie River, $(\mathrm{Z})=$ Zambezi River, standard length in $\mathrm{cm}$ ). Note time bar in ms. Waveform durations corrected to $25^{\circ} \mathrm{C}$ if necessary; the peak of the first head-positive phase (P1) normalized to 1 $(\mathrm{N}=$ head-negative phase; $\mathrm{P} 2=$ second (last) head-positive phase). 
(b) anteriorly lower and posteriorly higher, (c) anterior 10 or so rays longer than those posteriorly, (d) margin broadly rounded, (e) rays posterior to first 10 with distal margin straight, and (f) number of rays $25(N=6), 26$ $(N=20), 27(N=12), 28(N=1)$. Scales (a) cycloid with reticulate striae, except in centre and outer edge, (b) extending anteriorly to operculum, pectoral fins and pelvic fins. SPc, $15(N=2)$ and $16(N=37)$. Caudal peduncle slender and subcylindrical over the entire length, usually less than 7\% in SL. EOD triphasic with strong head-positive (P1), very strong head-negative $(\mathrm{N})$, and weak second head-positive phases (P2); long duration (close to $1 \mathrm{~ms}$; Figure 4).

Males approaching sexual maturity develop a kink in the base of the anal fin (Figure 1a) which is absent in juveniles and females where the anal fin base is straight (as in Figure 2c).

Colour in preservation. - Dorsally grey; laterally and ventrally including mouth region light ochre; dorsal and usually also lateral regions of head grey; the ventral light ochre sometimes extending to dorsal of the eye; fins whitish except tail fin that is of a light grey. Anterior edges of anal and especially dorsal fins darkened.

Ecology. - Although transformed by some river impoundment, the Sabie River in the Lowveld is a fast-flowing, major, perennial river, bordered by dense, subtropical or tropical vegetation. Water conductivity appears to be raised by human settlements and activities, both inside and especially outside the Park (upstream of the collection site).

Distribution. - The new species occurs in the Incomati River system of which the Sabie River forms part, the Blyde and the Letaba rivers that both drain into the Limpopo (a major and independent system, Figure 3), and in the Pongola River (Natal), its southernmost record.

Relationships. - Petrocephalus wesselsi is considered closest to $P$. catostoma based largely on the confusion of the identity of both species. The clearest distinction from $P$. catostoma, as represented by Ruvuma type specimens, is a relatively shorter CPL (also detected in the pD measure that includes CPL) but greater HL in P. wesselsi. P. wesselsi is most easily distinguished from $P$. catostoma (as represented by our Upper Zambezi specimens) by modal nD 20 vs. 22-23, modal nA 26-27 vs. 28-29, and SPc 16 vs. 12.
P. wesselsi also has a deeper CPD, shorter LD and LA, dorsal fin origin situated closer to head, greater separation of $\mathrm{Na}$, less $\mathrm{BD}$, shorter $\mathrm{LS}$, snout not as broadly rounded, and has a much longer-lasting EOD (more than two times), and the amplitude of P2, as compared to $\mathrm{P} 1$, is about one third. Between the Sabie and the Upper Zambezi populations there are seven fixed allele mobility differences out of 26 studied (Van der Bank 1996), a clear indicator of a species differentiation.

We confirm Gilchrist \& Thompson's (1913) description of their single specimen from Leydsdorp (Northern Province, Limpopo system), then determined as P. stuhlmanni (corresponding to our new species), and confirm the distinction from the Upper Zambezi form of $P$. catostoma (1913) these authors made. However, we cannot revive stuhlmanni for South African specimens for two reasons. (1) Morphology: SPc is 12 in P. stuhlmanni vs. 16 in all South African Petrocephalus populations studied. As intra-population variability in this character is only a single count in all Petrocephalus populations studied in the present paper, it is extremely unlikely $P$. stuhlmanni should vary by four. (2) Geography: the type locality of $P$. stuhlmanni is the 'Kingani River, East Africa' which is now known as the Ruvu, a small coastal river reaching the Indian Ocean at the town of Bagamoyo just north of Dar es Salaam in Tanzania ( $6^{\circ} 27^{\prime} \mathrm{S}$; P. Skelton personal communication). This is about $2000 \mathrm{~km}$ north of the Limpopo and still $450 \mathrm{~km}$ north of the type locality for $P$. catostoma, the Ruvuma River. Therefore, the type locality for $P$. stuhlmanni is the most remote locality in relation to the South African localities studied in the present paper.

Etymology. - The new species is named in honour of Pierre Wessels (Johannesburg), late participant of our expeditions to Caprivi, nature conservationist and good friend.

Additional material. - Two specimens from the Groot Letaba River just below Tzaneen Dam (South Africa, Northern Province), $23^{\circ} 49^{\prime} 00^{\prime \prime}$ S, $30^{\circ} 10^{\prime} 00^{\prime \prime}$ E, 22 September 1998, water conductivity and temperature: $114 \mu \mathrm{S} \mathrm{cm}^{-1}, 21.4{ }^{\circ} \mathrm{C}, 53$ and $61 \mathrm{~mm} \mathrm{SL}$. Six specimens from Blyde River just below Swa-

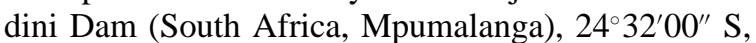
$30^{\circ} 47^{\prime} 05^{\prime \prime}$ E, 25/26 September 1998, water conductivity and temperature: $154 \mu \mathrm{S} \mathrm{cm}^{-1}, 16.7^{\circ} \mathrm{C}$, size range $82-90 \mathrm{~mm}$ SL. Both rivers are tributaries of the Olifants River that forms part of the Limpopo system. This material was studied for EODs (field recordings; seven 
fish) and morphology (eight fish). One male specimen from the Pongola River $\left(27^{\circ} 1^{\prime} \mathrm{S}, 32^{\circ} 18^{\prime} \mathrm{E}\right.$, road from Ndumo to Kosibay at bridge crossing the Pongola River), 14 August 1999, water conductivity and temperature: $600 \mu \mathrm{S} \mathrm{cm}^{-1}, 22^{\circ} \mathrm{C}, 79 \mathrm{~mm}$ SL. The dark on the back of the body and the head gradually becomes lighter towards the lateral line where the dark intensifies to a fine dark line on either side. Ventral parts are a light grey like in the other South African Petrocephalus samples.

\section{Results}

\section{Gonad histology}

In spite of a high and rapidly flowing Sabie River at the time of capture (local autumn), the reproductive season was over for $P$. wesselsi. Oocytes of up to stage III were found in ovaries (terminology, Takashima \& Hibiya 1995), a stage that seems typical for reproductive quiescence in female mormyrids (Kramer 1997a). The maximum oocyte diameter recorded in the total sample was $240 \mu \mathrm{m}$. Testes were completely regressed. No (or exceedingly little) sperm was present in any of the males, and the lumen of testicular canals was reduced to almost zero. No cysts indicating ongoing spermiogenesis were seen. A similarly inactive picture has been described for Zambezi P. catostoma that were collected at the end of local winter (Kramer 1997a).

\section{Electric organ discharges}

This section is based on a comparison of South African vs. Upper Zambezi (Namibian) live specimens of churchill, as East African forms of Petrocephalus were unavailable to us. All live specimens of Petrocephalus studied in the present paper displayed a basically similar, triphasic EOD waveform: headpositive P1-phase, strong head-negative N-phase, weak head-positive P2-phase. The $2 \times 4$ examples shown in Figure 4 were recorded from adults of similar SL. EODs from specimens from the Blyde, Letaba and Pongola rivers resemble those from the Sabie so closely that they are not shown. As expected from their shorter duration, EOD amplitude spectra for the four Zambezi fish shown in Figure 4 are more high-frequency and of broader bandwidth than those for the four Sabie fish (Figure 5). Peaks of amplitude spectra ranged from
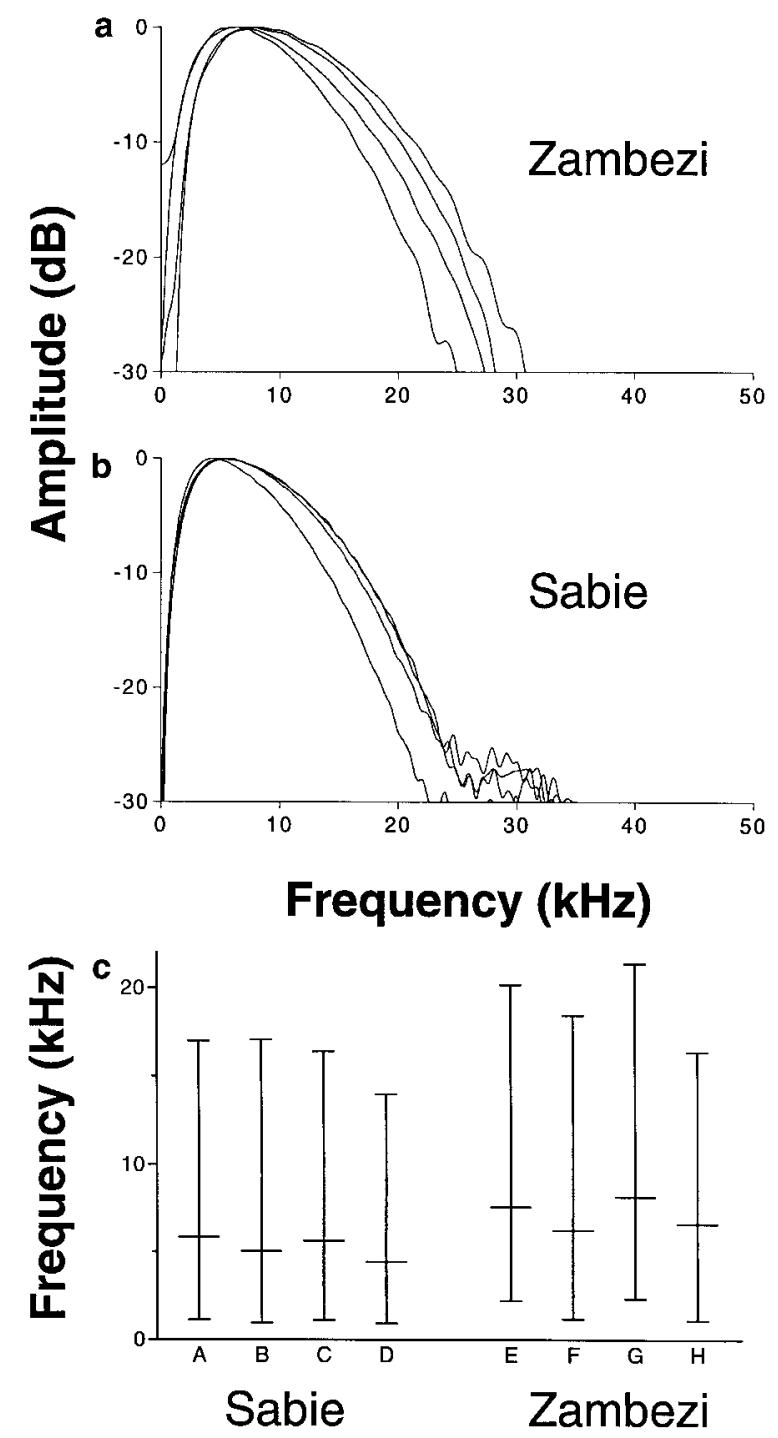

Figure 5. Fourier amplitude spectra of the EODs shown in Figure 4. $\mathrm{a}-$ Zambezi fish; $\mathrm{b}-$ Sabie fish. Frequency resolution, $<1 \mathrm{~Hz}$. Ordinate, amplitude in $\mathrm{dB}$ (re: the strongest component of a spectrum $=0 \mathrm{~dB}$ ); abscissa, frequency in $\mathrm{kHz}$. $\mathrm{c}-$ Shows the $-10 \mathrm{~dB}$ bandwidth (re: peak amplitude $=0 \mathrm{~dB}$ ) of the Fourier amplitude spectra $(a, b)$, for fish from the Sabie (individuals $a-d$ ) and the Zambezi (e-h). Also indicated is the frequency of peak amplitude (horizontal bar) for each spectrum. Ordinate, frequency in $\mathrm{kHz}$.

$4414-5834 \mathrm{~Hz}$ in these fish from the Sabie, and 6232$8142 \mathrm{~Hz}$ in those from the Zambezi, whereas the frequencies of $-10 \mathrm{~dB}$ amplitudes of the spectra are not as well separated, with a tendency to higher values for the Zambezi fish (Figure 5c). 
All EOD waveform parameters studied, except two, varied with SL at least in one of the two species (Table 1), as shown by least-squares regression analyses followed by runs tests for nonlinearity (with negative results in all cases). The results are presented as regression lines with their associated scatter among individuals (Figures 6-8). One of the most conspicuous EOD waveform differences between the two species is the weak amplitude of P2 (relative to P1 amplitude = 1) in fish from the Sabie (including those from the Letaba, Blyde and Pongola rivers) compared to those from the Zambezi (Figure 6). There is a significantly negative correlation of P2 amplitude with SL in both species (Table 1), except for juveniles from the Upper Zambezi (no correlation; Kramer 1997a,b). Our smallest fish from the Sabie was $5.9 \mathrm{~cm} \mathrm{SL}$ and determined not to be a juvenile as defined by the ' $40 \%$ rule' (sexual maturity possible at about $40 \%$ of the maximum species size which is $13 \mathrm{~cm}$ in $P$. catostoma and probably similar for $P$. wesselsi; Kramer 1994, based on field observations by Blake 1977 and Kolding et al. 1992, and later confirmed by Kramer 1997a).

The cryptic sex difference that had been observed in Upper Zambezi fish, with male EODs showing, on average, a stronger P2 phase than EODs of females of the same size (the slopes of the regression lines, in contrast to their elevations, being not significantly different, and pooled in Table 1), is not present in the Sabie sample. The data for P2 amplitude as well as for all other EOD parameters of Sabie fish studied were pooled for the two sexes because the differences were not significant in each case: $\mathrm{p}>0.05$ for both slopes and Y-intercepts of regression lines.

The largest Sabie specimens showed an almost biphasic EOD waveform (also seen in the largest fish from the Limpopo system), owing to the negative correlation of P2 phase amplitude with fish size. There was no overlap of the distinctly separate points for adult Sabie, Limpopo and Pongola system fish on one hand, and adult Zambezi fish on the other (Figure 6). The regression line slope was significantly less steep for Sabie fish than Zambezi fish (Table 1). Also for amplitude of the head-negative $\mathrm{N}$ phase (again relative to P1 phase $=1$ ), Zambezi fish, on average, show higher values than Sabie fish. There is a statistically significant negative correlation of $\mathrm{N}$ amplitude with SL in Sabie fish not present in Zambezi fish. The slopes of the regression lines differ significantly between the two species. The two small fish from the Letaba River showed the strongest $\mathrm{N}$ amplitudes of all fish studied, whereas fish from the Blyde and Pongola rivers fell within the range shown by the Sabie fish.

Very marked differences between the two species were found for the durations of the P1 and the P2 phase, with the Sabie fish displaying the higher values (Figure 7). P2 phase duration is one of two (out of a total of 12) EOD parameters studied in which neither of the two fish species show a correlation with fish size (regression lines horizontal); therefore, means with standard errors are given (Table 1). In spite of their weak $\mathrm{P} 2$ phase amplitudes (Figure 6), Sabie fish display a P2 phase duration that is, on average, almost three times that of Zambezi fish ( $\mathrm{p}<0.0001)$. In contrast to fish from the Sabie, P1 phase duration of Zambezi fish is correlated negatively with fish size, and the difference between the regression lines slopes is significant. Fish from the Limpopo and Pongola systems fit well into the scatter of the Sabie fish, with a tendency to still longer durations especially for P1 phase.

Also for $\mathrm{N}$ phase, and especially total EOD duration, Sabie, Limpopo and Pongola system fish range well above Zambezi fish (Figure 7). In spite of a positive correlation of $\mathrm{N}$ phase duration with SL (not found in Zambezi fish) that was accentuated by similar correlations in two out of the three measures for the intervals between EOD peaks (N-P2 separation and P1-P2 separation, Figure 8), total EOD duration (Figure 7) is not correlated with size in Sabie fish. This contrasts with a significantly negative correlation for EOD duration in Zambezi fish although an F-test shows no significant difference between the regression line slopes. However, the elevation (Y-intercept) of the regression line for the Sabie fish is significantly higher $(\mathrm{p}<0.0001)$ than that for the Zambezi fish (Table 1). Also negatively correlated is the interval between $\mathrm{P} 1$ and $\mathrm{N}$ peaks (P1-N separation) with fish size in Zambezi, but not in Sabie fish (no correlation). All three interval measures (Figure 8) differ significantly in regression line slopes between the two species.

Neither P1 nor $\mathrm{N}$ phase area depend on SL in Sabie fish although in Zambezi fish, values are smaller and P1 phase area negatively correlated with fish size (Figure 8; borderline case with $\mathrm{p}=0.0502$ for $\mathrm{N}$ area). The lack of size correlation of $\mathrm{N}$ phase area in Sabie fish seems to result from the compensation of a positive correlation (with size) of $\mathrm{N}$ phase duration, by a negatively correlated $\mathrm{N}$ phase amplitude. $\mathrm{P} 1$ phase duration in Sabie fish is not size correlated, and so is P1 phase area. However, P2 phase area in Sabie fish is negatively size-correlated, whereas there is no such correlation in 


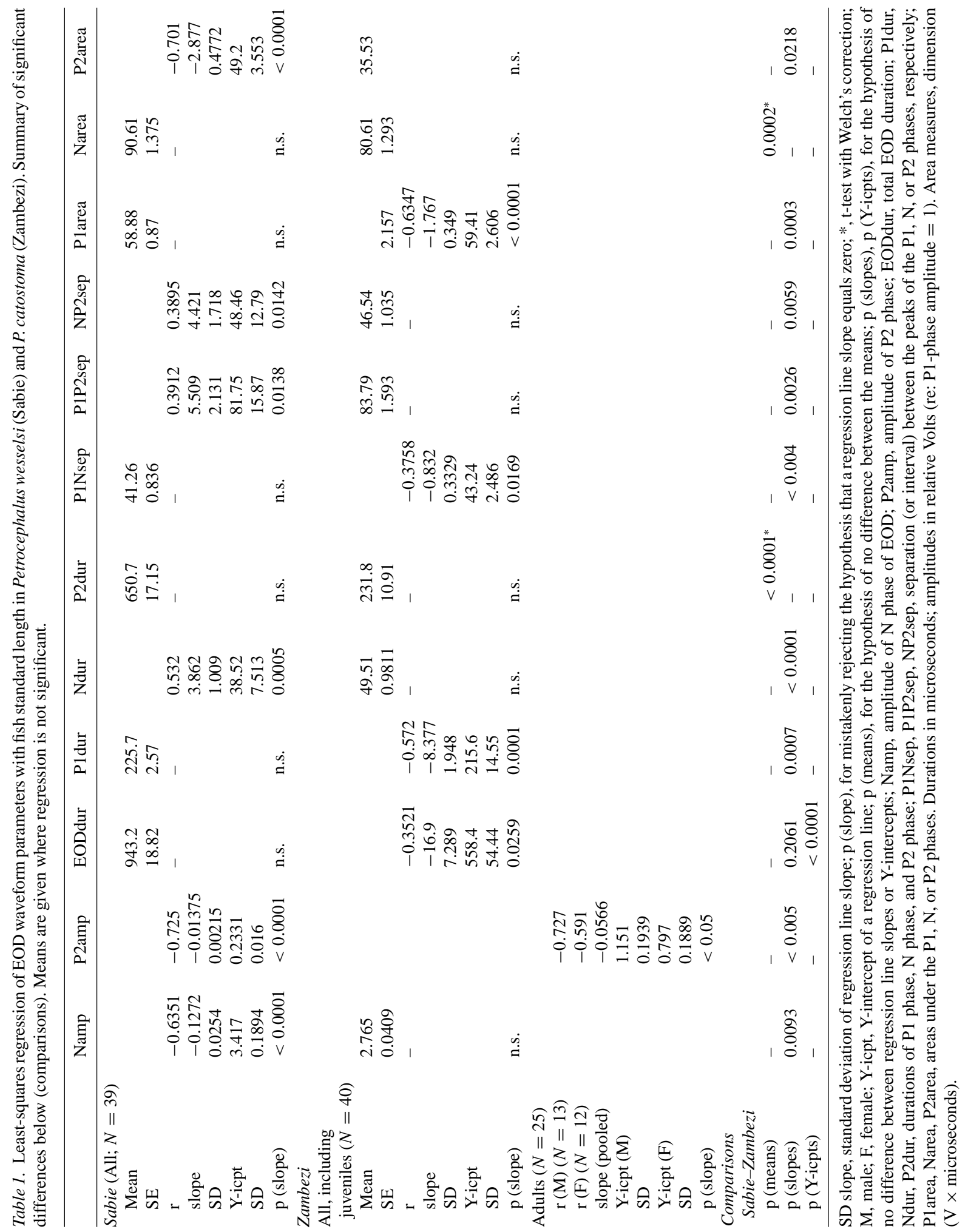




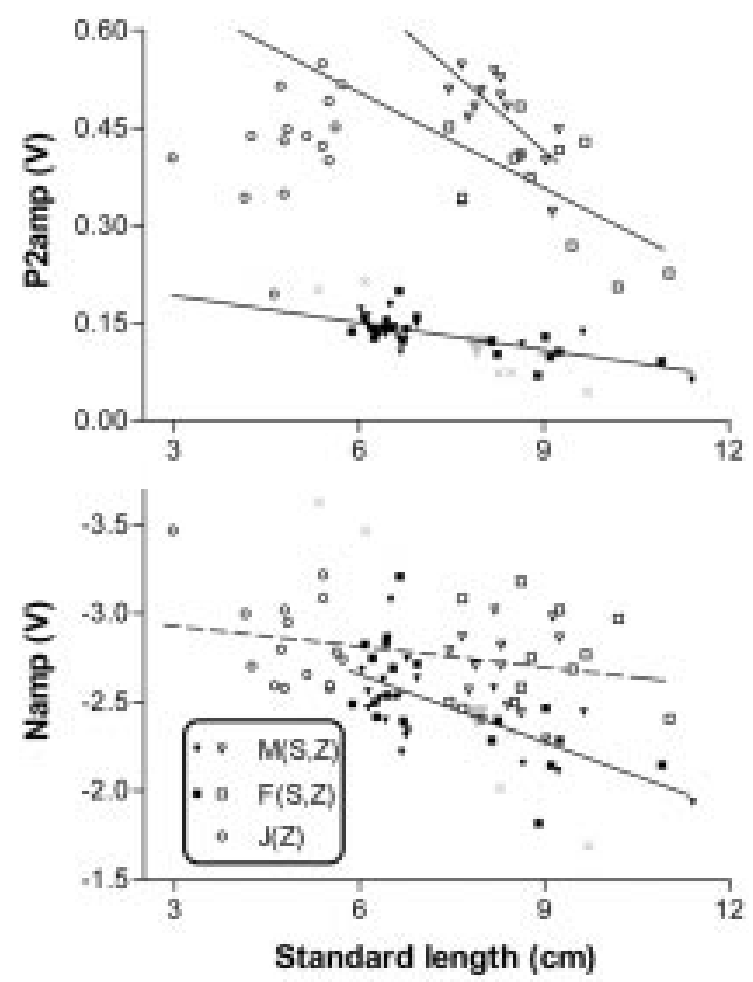

Figure 6. The dependence of EOD waveform parameters on standard length $(\mathrm{cm})$ for fish from the Sabie (filled symbols) and the Upper Zambezi rivers (open symbols). P2amp = amplitude of the P2 phase of an EOD; Namp = amplitude of the $\mathrm{N}$ phase both relative to $\mathrm{P} 1$ phase amplitude $=1$ (see Figure 4). Leastsquares regression lines are significantly different from zero correlation (line), or non-significant (dashed). $\mathrm{M}(\mathrm{S}, \mathrm{Z})=$ legend for symbols for Sabie or Zambezi males; $F(S ; Z)=$ for females; $\mathrm{J}(\mathrm{Z})=$ juveniles from the Zambezi. $\times$ 's for seven fish of indeterminate sex from the Limpopo system (not included in the statistical analyses); the two smallest fish are from the Letaba River, the others from the Blyde. Large triangle = single male specimen from the Pongola River (Natal).

Zambezi fish which display the higher values. This is in agreement with the negative correlation of $\mathrm{P} 2$ phase amplitude with size in Sabie fish (Figure 6) which is not compensated for by an increase in P2 phase duration that remains constant over the whole size range (Figure 7). In spite of the weak amplitude of the P2 phase found in Sabie fish, P2-phase area values are surprisingly high, although smaller compared to those observed in Zambezi fish (Figure 8). This paradox is explained by the very long duration of the P2 phase in Sabie fish (Figure 7). Means and regression line slopes are significantly different between species for all three 'area' measures (Table 1). In Figure 8, fish from the Limpopo system (including the single Pongola specimen) tend to fall among the values for Sabie fish, or to show values more extreme, separating some of these South African fish still more from Zambezi fish than what was observed for Sabie fish.

\section{Morphology}

Table 2 lists means (or medians for counts) and ranges of the morphological measures for the four forms of Petrocephalus studied (from South African, Upper Zambezi, and two from East African origin). For the three meristic measures $\mathrm{nA}, \mathrm{nD}$ and $\mathrm{SPc}$, least-squares regression with size is not significant (Table 3; SPc, not shown). This contrasts with all of the 11 morphometric measures. The median SPc is only 12 in fish from the Upper Zambezi vs. 16 in fish from the Sabie, Limpopo and Pongola, with extremely little variation (for the Sabie, the $25 \%$ and $75 \%$ percentiles are identical with the respective medians in both cases; $\mathrm{p}<0.0001$; Mann-Whitney $U$-test). Because of some caudal peduncle scales missing in the four paratype specimens from the Ruvuma River, collected in 1863 , the numbers given in Table 2 are approximate estimates (a minimum of 15 and a maximum of 16 or perhaps 17 scales). In the lectotype, these scales were all gone and no estimate was attempted. P. stuhlmanni markedly differed from $P$. catostoma types by its low SPc (12). This is surprising given the relative geographic proximity and the synonymisation by Whitehead \& Greenwood (1959).

In contrast to the scale count, $\mathrm{nD}$ and $\mathrm{nA}$ are significantly lower in fish from the Sabie than Upper Zambezi, and the ranges for the dorsal fin overlap for a single count, only (18-21 versus 21-25; medians, 20 and 23, respectively; $\mathrm{p}<0.0001 ; t$-test). The $25 \%$ percentile (22) of the higher median is well above the $75 \%$ percentile (20) of the smaller median, underlining the clear separation of distributions. Although the distributions of anal fin rays overlap more extensively, the medians of 26 for the Sabie fish and 28 for the Upper Zambezi fish (with an associated $25 \%$ percentile of 28, Upper Zambezi, and a $75 \%$ percentile of 27 , Sabie), show a degree of separation of distributions only slightly less marked ( $\mathrm{p}<0.0001$; Welch's $t$-test because of significantly different variances) than for the dorsal fin ray numbers. Our fish from the Limpopo system showed count ranges within those for the Sabie fish, except for two specimens, both from the Blyde River: one 

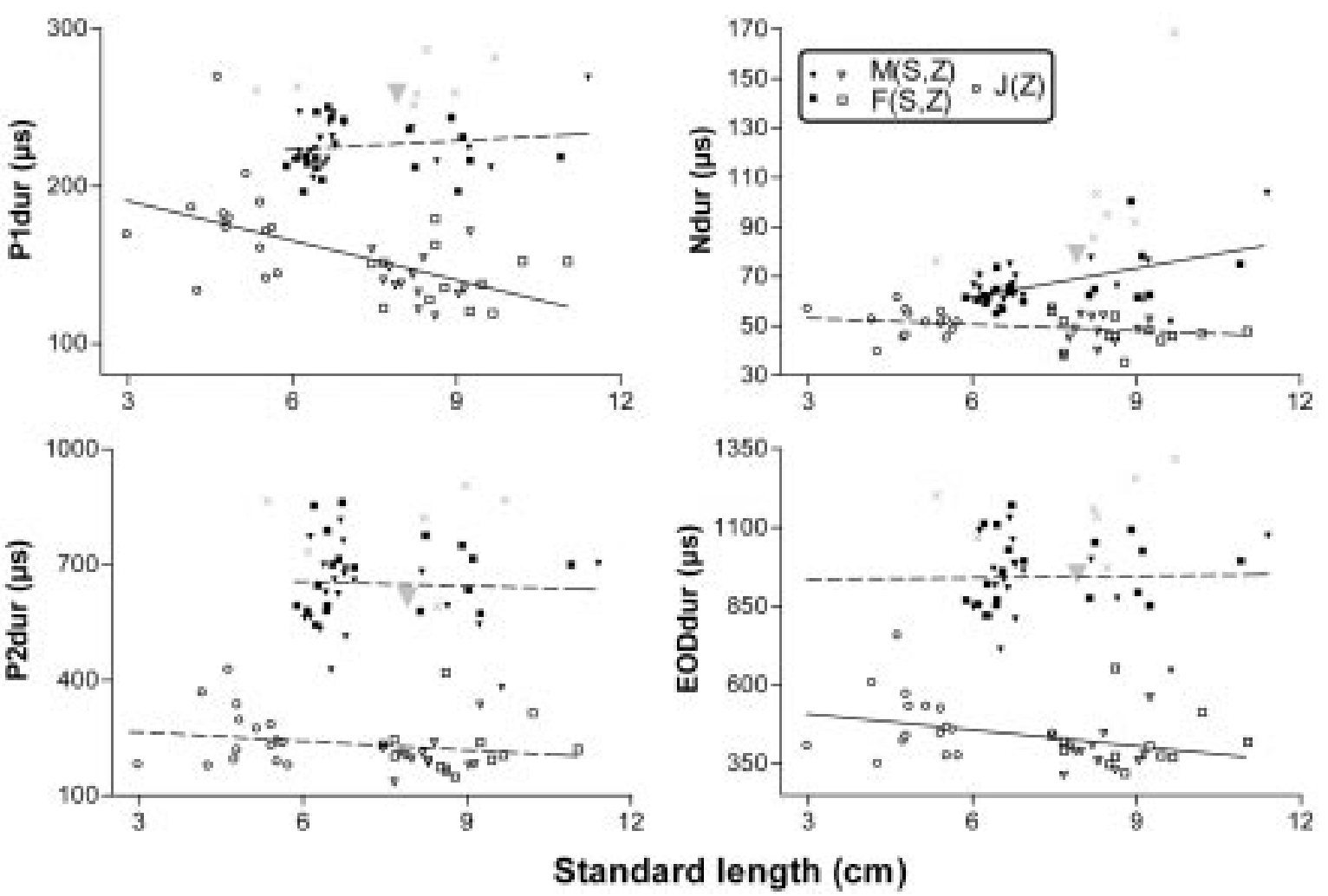

Figure 7. The dependence of EOD waveform parameters on standard length (cm) for fish from the Sabie (filled symbols) and the Upper Zambezi rivers (open symbols). P1dur $=$ duration of the P1 phase of an EOD; P2dur $=$ duration of the P2 phase; Ndur $=$ duration of the $\mathrm{N}$ phase of an EOD; EODdur = total EOD duration (see Figure 4). Least-squares regression lines are significantly different from zero correlation (line), or non-significant (dashed). $\mathrm{M}(\mathrm{S}, \mathrm{Z})=$ legend for symbols for Sabie or Zambezi males; $\mathrm{F}(\mathrm{S} ; \mathrm{Z})=$ for females; $J(Z)=$ juveniles from the Zambezi. $\times$ 's for seven fish of indeterminate sex from the Limpopo system (not included in the statistical analyses); the two smallest fish are from the Letaba River, the others from the Blyde. Large triangle = single male specimen from the Pongola River.

with the highest pericaudal scale count of 17 of all fish of the present study, and another one with the lowest dorsal fin ray count observed (17). This removes the ranges for our Limpopo fish still more from those of the Upper Zambezi than what was observed in the Sabie fish. Similar to SPc, the Ruvuma type specimens showed $\mathrm{nD}$ and $\mathrm{nA}$ counts within the range of Sabie and Limpopo fish (no difference), but clearly different from Upper Zambezi fish. Our single Pongola specimen was within the range for Sabie fish also for $\mathrm{nA}$ and $\mathrm{nD}$. P. stuhlmanni differed from Upper Zambezi specimens by its low $\mathrm{nD}$ count (19).

The morphometric measures depend on fish size in a linear way, as shown by least-squares regression analyses followed by runs tests for nonlinearity (with negative result in all cases, Table 3; Ruvuma and Kingani/Ruvu type specimens not included because of the small sample size). With the exception of HL, PAL and CPL, all of the morphometric characters also differ significantly between the two locations. For example, LD and LA are longer in Zambezi than in Sabie fish of the same size, as demonstrated by a significantly higher elevation (Y-intercept) of the regression lines for the Zambezi fish compared to those for the Sabie fish that are parallel (differences in slope, not significant; Table 3). This corresponds well with the higher number of fin rays in Zambezi compared to Sabie fish. Another correspondence with a meristic measure is the larger increase (steeper regression line slope) of CPD with size, and SPc is higher in fish from the Sabie. A 

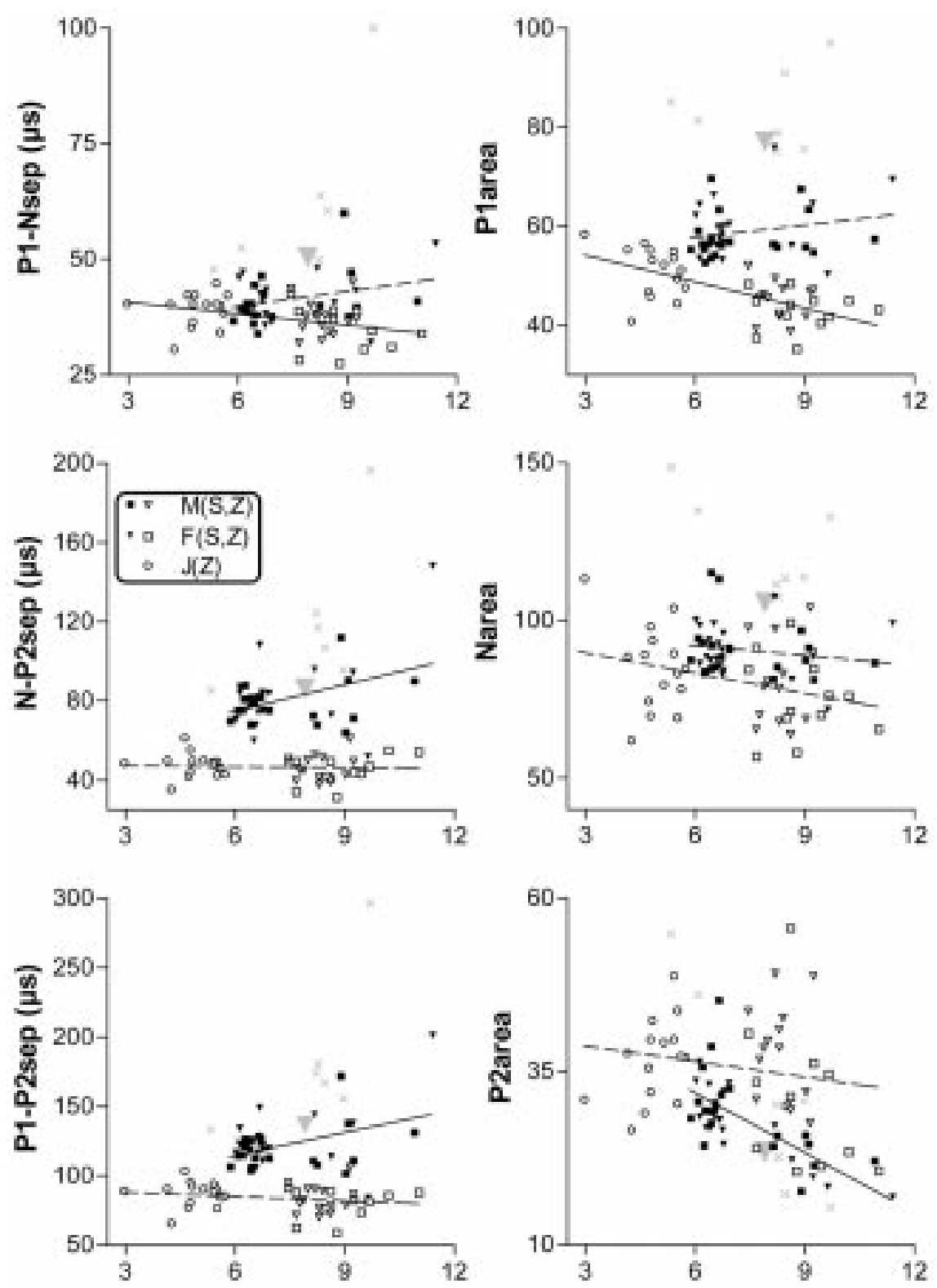

\section{Standard length $(\mathrm{cm})$}

Figure 8. The dependence of EOD waveform parameters on standard length $(\mathrm{cm})$ for fish from the Sabie (filled symbols) and the Upper Zambezi rivers (open symbols). P1-Nsep = interval separating the peak of the P1 phase from that of the N phase of an EOD; $\mathrm{N}-\mathrm{P} 2 \mathrm{sep}=$ same for the peaks of the $\mathrm{N}$ and the P2 phases; same for the peaks of the P1 and the P2 phases. P1area $=$ area under $\mathrm{P} 1$ phase of an EOD; Narea $=$ same for $\mathrm{N}$ phase; P2area $=$ same for P2 phase, all in $(\mathrm{V} \times \mu \mathrm{s})$, with Volts relative to P1-phase amplitude $=1$ (see Figure 4). Least-squares regression lines are significantly different from zero correlation (line), or non-significant (dashed). $\mathrm{M}(\mathrm{S}, \mathrm{Z})=$ legend for symbols for Sabie or Zambezi males; $\mathrm{F}(\mathrm{S} ; \mathrm{Z})=$ for females; $\mathrm{J}(\mathrm{Z})=$ juveniles from the Zambezi. $\times$ 's for seven fish of indeterminate sex from the Limpopo system (not included in the statistical analyses); the two smallest fish are from the Letaba River, the others from the Blyde. Large triangle = single male specimen from the Pongola River. 


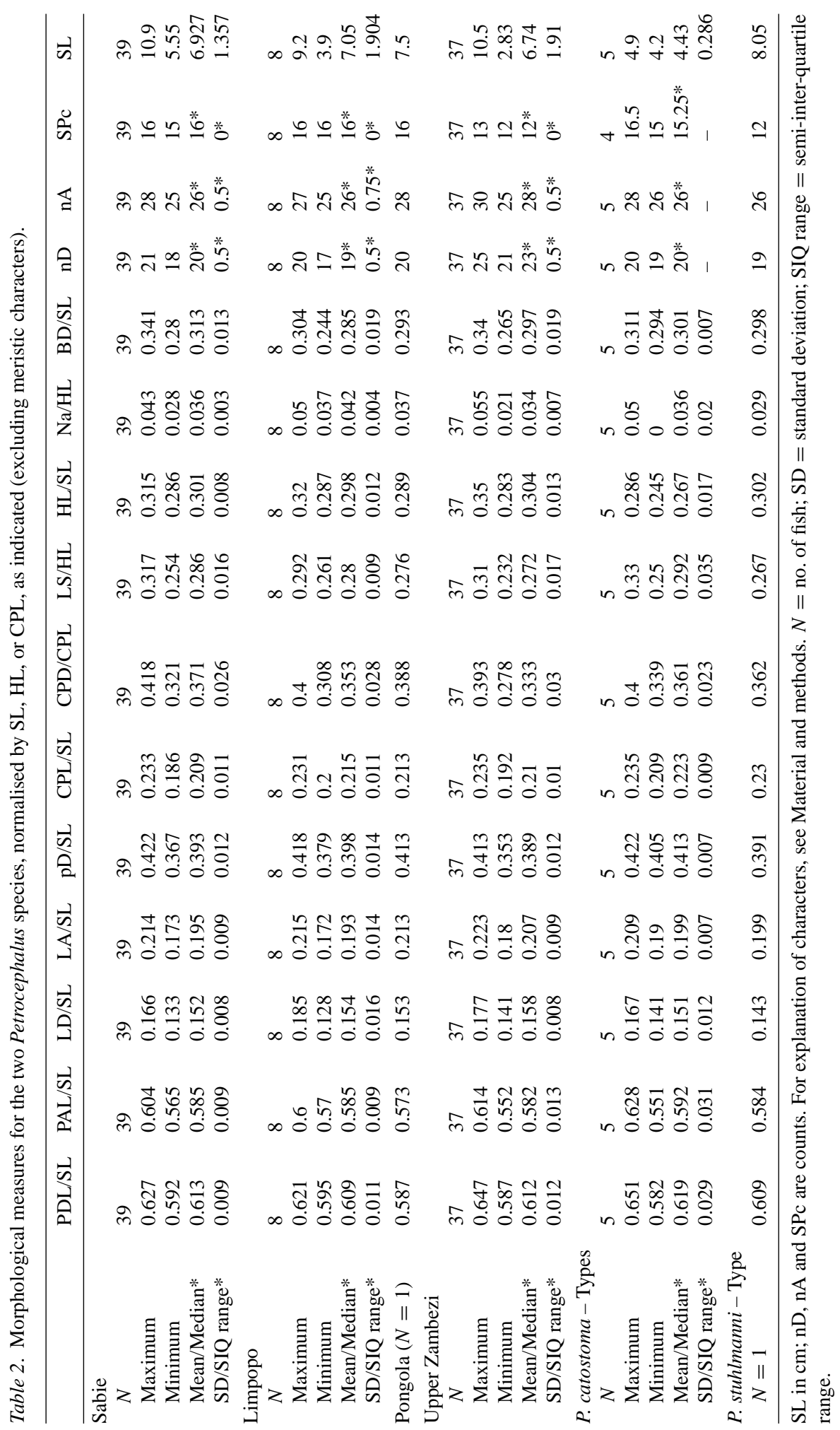




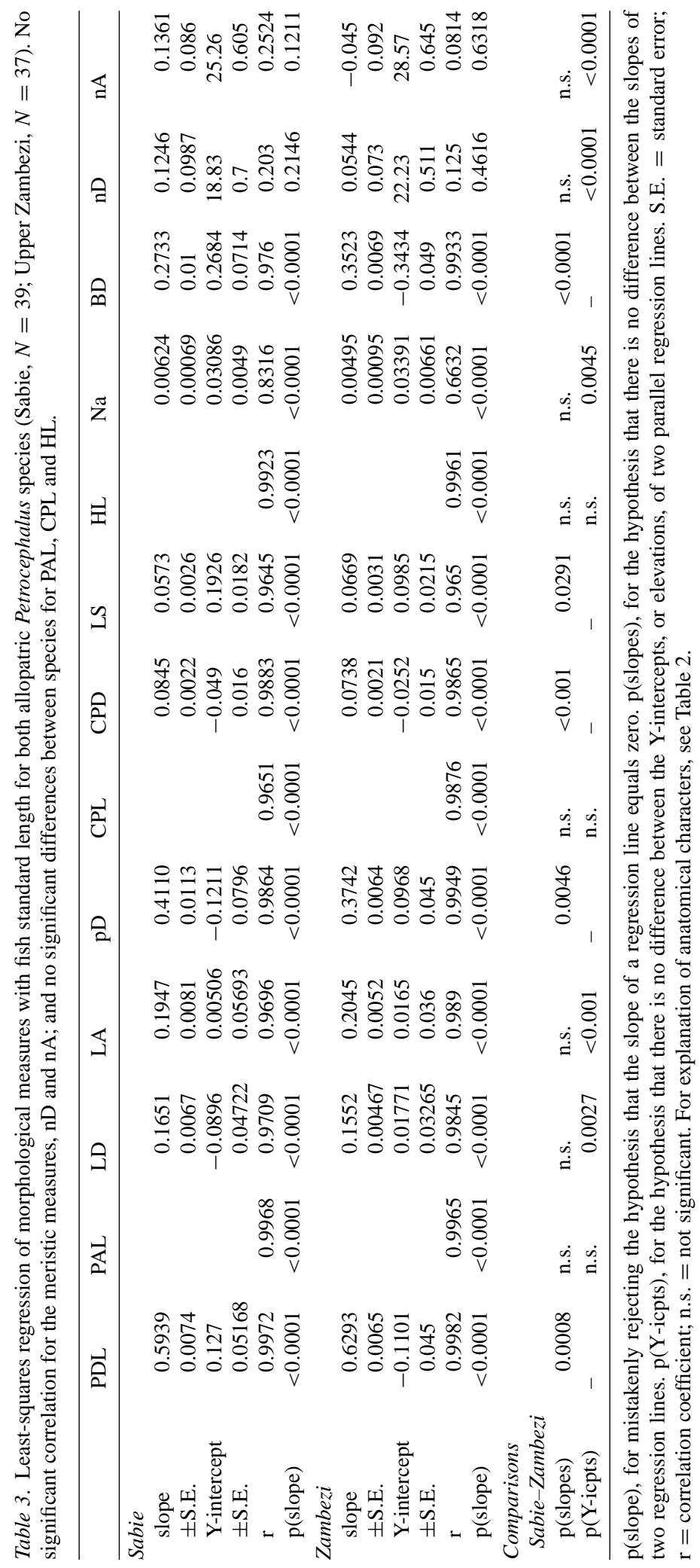


larger increase with size in fish from the Sabie is also found for $\mathrm{pD}$. However, in all other characters where there is a difference between the two species, it is the fish from the Zambezi in which either a larger increase with size is found (BD, PDL, LS), or else higher values for fish of the same size because of a difference in elevation of parallel regression lines $(\mathrm{Na})$.

Since LS increases relatively more with size in Zambezi fish, in spite of there being no difference in regression parameters for HL, the eye seems to move farther backwards during ontogeny in Zambezi fish compared to Sabie fish. The steeper growth of $\mathrm{pD}$ in Sabie fish probably signals that the dorsal fin is positioned more anteriorly in Sabie fish because there is no difference for CPL between both species of fish, and LD is even longer in Zambezi than in Sabie fish of the same size. This hypothesis is supported by the observation of a stronger growth of PDL in Zambezi compared to Sabie fish.

Morphological measures tend to be correlated amongst each other, and a single analysis of all outcomes as related to the independent variable, origin, is desirable. Therefore, a multivariate analysis of variance (MANOVA) was performed; simultaneous univariate ANOVAs can identify the source of the difference, if present (Table 4). Normalised morphological measures were used in order to compensate for different size of the fish. Counts were not normalised as they are not correlated with fish size. SPc was excluded from the analysis because the lectotype lacked all caudal peduncle scales, and including this character would bring down $N$ from 5 to 4 for the group of 'types' (empty cell problem). Na was excluded because of a high variability perhaps due to measurement error of this extremely small measure. The single specimen of $P$. stuhlmanni could also not be included in this analysis.

The null hypothesis stating that our fish of different origin are all similar in morphology can definitely be rejected because of a MANOVA result of $\mathrm{p}<0.0001$ (Table 4). The univariate ANOVAs show significant differences for the meristic characters $\mathrm{nA}$ and $\mathrm{nD}$ (which is no surprise, see above), but also for BD, HL, LS, CPD, pD, LA and LD. The only characters that did not show any differences were PDL and PAL. As expected, the multivariate analysis clearly confirms the differentiation of South African specimens from Upper Zambezi fish, in 7 characters. This obvious result confirms those derived from EOD data, genetic data, and morphology regression analyses (see above).
A more interesting question is whether or not there is any evidence for the $P$. catostoma types being distinct from the Sabie/Limpopo group. As shown above, the meristic characters are similar or identical and do not by themselves support the idea of a new species of Petrocephalus for South Africa. However, even though $N$ is only 5 for the group of types, significant morphological differences between types and Sabie fish are demonstrated. Compared to Sabie fish, the rear section of type specimens (pD), including CPL, is longer $(\mathrm{p}=0.0093)$ whereas their head (HL) is shorter $(\mathrm{p}<$ 0.0001 ). Differences in body proportions such as these are of a more fundamental nature that is not known to be correlated with, e.g., food availability affecting characters such as BD, and support a new South African Petrocephalus species that is distinct from the types.

An unexpected result is the differentiation of Upper Zambezi specimens with regard to Ruvuma types ( $\mathrm{pD}$, HL, nD, nA, Table 4; and also Spc, Table 2). This seems to point to a need for studying also the relationship of $P$. catostoma specimens from the Upper Zambezi and $P$. catostoma, as represented by the types. Furthermore, there seems to be a difference between $P$. catostoma types and our single $P$. stuhlmanni type (e.g., in pD, $\mathrm{HL}$, and SPc) in spite of their common Eastern African origin. To tackle these questions would require collecting new specimens from the type localities, and is beyond the scope of the present study.

\section{Discussion}

Based on allozyme data, Van der Bank (1996) calculated a large genetic distance value (Nei 1978) of 0.311 for two of the allopatric populations of $P$. catostoma that were studied in the present paper, those from the Upper Zambezi and Sabie. A degree of genetic differentiation that high is typical for congeneric species, and far beyond what has been observed in intraspecific populations (up to 0.07; Van der Bank 1996). Because there were also fixed allele mobility differences at seven of the 26 protein coding loci studied, Van der Bank (1996) suggested the existence of an undescribed species for the Sabie River system in South Africa. To study the question in more detail we chose morphology and EOD as the most likely fields for relevant differences between populations.

For Petrocephalus from the Upper Zambezi and the Sabie, the present study confirmed differentiation on the species level by the analysis of morphology 


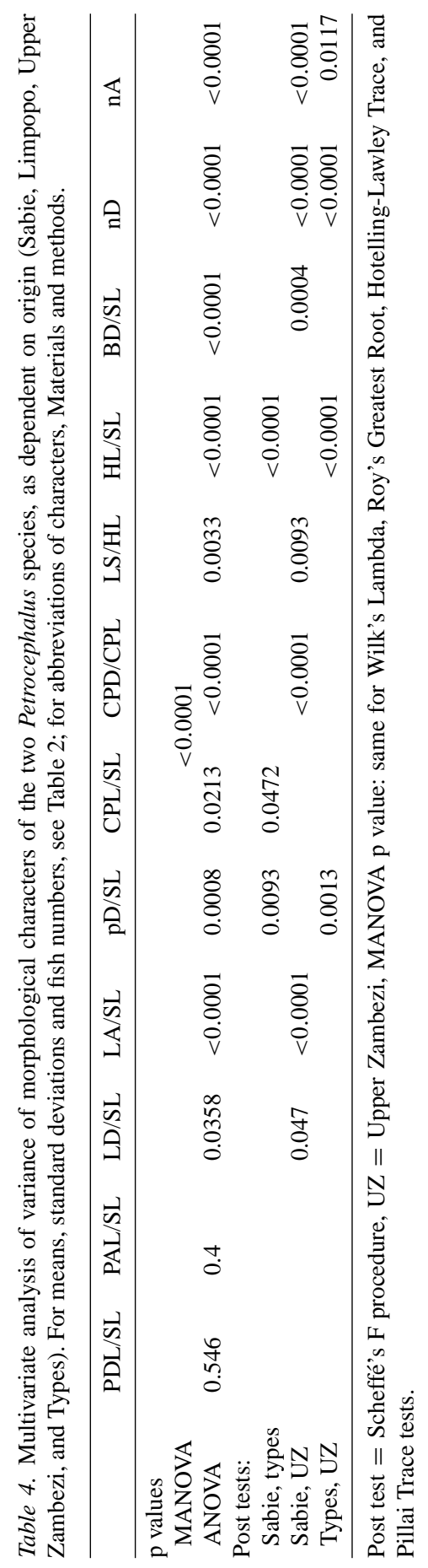


and EOD. Among 14 anatomical characters studied (Table 3), 11 differed significantly between South African and Upper Zambezi specimens, including all meristic characters (that is, $\mathrm{SPc}, \mathrm{nD}$ and $\mathrm{nA}$ ). Eight morphometric characteristics (out of 11) either differed significantly in the slope of a regression line showing the correlation with fish size, or the elevation of parallel lines. Whereas a steeper rate of growth of BD in Zambezi fish compared to those from the Sabie may be linked to more favourable food or climate conditions, other anatomical differences (e.g., CPD steeper growth in Sabie fish; length of unpaired fins, etc.; Table 3) are more difficult to explain in this way. Additional material from the Limpopo system and the Pongola River agrees well with that from the Sabie (Table 2).

The EOD is this nocturnal fish's principal means of communication, and of key importance for mating to occur in the single species studied (Bratton \& Kramer 1989, Crawford 1991). In each of 12 EOD waveform parameters analysed, differences are significant (Table 1). These differences are not only of degree (e.g., P2 phase duration in Sabie fish averages 2.8 times that of Zambezi fish), but also of principle. Whereas in Zambezi fish there is a cryptic sex difference in P2 amplitude, no such difference is found in Sabie fish. The duration of the $\mathrm{N}$ phase is positively correlated with size in Sabie fish (hence, $\mathrm{N}$ amplitude negatively correlated), compared to no such correlations in Zambezi fish. Other differences concern P1 phase duration, the intervals between the peaks of the EOD, and area-under-curve measures. Similar to morphological analysis, EOD recordings from additional material sampled from the Limpopo system and the Pongola River suggests that the new species is the only Petrocephalus species present in South Africa (Figures 6-8).

It is interesting to note that already Gilchrist \& Thompson distinguished between an Upper Zambezi Petrocephalus species (P. catostoma; 1917), and one for South Africa (P. stuhlmanni Boulenger; 1913, Limpopo System). We suggest a similar distinction although we cannot revive stuhlmanni for South African Petrocephalus since this name originally refers to fish of the distant Kingani (= present-day Ruvu) River in Tanzania (synonymised with $P$. catostoma by Whitehead \& Greenwood 1959). Even though there is only a single specimen of $P$. stuhlmanni available, there is clear morphological differentiation (SPc) from South African Petrocephalus specimens.
We therefore compared our fish from the Upper Zambezi and South Africa with the type material of $P$. catostoma. Because of the very small number of type specimens $(N=5)$ available, the clear rejection of the null hypothesis of no morphological difference from our South African specimens (with a much larger sample size) is astounding ( $p<0.01$, Table 4$)$. Only when differences are very consistent such a clear result may be expected under adverse circumstances. We conclude that the South African specimens represent a new species, $P$. wesselsi, that is distinct from both the $P$. catostoma and $P$. stuhlmanni types, and the Upper Zambezi specimens as well. Since there was also significant differentiation of Upper Zambezi specimens from $P$. catostoma types in even more characters, we suggest that the synonymisation with $P$. catostoma be revised. The synonymisation of $P$. stuhlmanni with $P$. catostoma also needs confirmation. To revise these synonymisations is, however, next to impossible at present because of the paucity, age and sometimes conservation status of the type material. It would also be interesting to study genetic and EOD differentiation among South African, Upper Zambezi and type locality specimens but that requires sampling live specimens from the type locality, specimens that are unavailable at present.

Under Paterson's 'recognition concept' (see Introduction), speciation is an incidental effect of allopatric separation caused by differences in selection pressures. The founder effect and genetic drift are possible contributing factors. Both mormyrid species of the Sabie [P. wesselsi; Marcusenius macrolepidotus (Peters, 1852)] belong to a primary, tropical freshwater family endemic to Africa, and are thought to be descendants of populations of the Okavango-Upper Zambezi River system whose originally western orientation (to the Atlantic Ocean) changed in the mid Tertiary when the outlet to the sea became the Limpopo valley (Indian Ocean). This arrangement probably only ended in the late Pliocene when the Upper Zambezi was diverted further north by the encroaching middle and lower Zambezi (reviews in Skelton 1993, 1994).

How can differences between allopatric populations as large as the ones described in the present paper evolve in, apparently, a relatively short time span (separation probably in the late Pliocene, 1.8-2 Myr ago)? Character displacement, or rather its reversal, may have played a major role in this speciation: (1) The mormyrid fish community of the Upper Zambezi comprises seven species, one of which is $P$. catostoma, and the spectral 
low-frequency range for EOD is well occupied by several species, for example, Mormyrus lacerda Castelnau, 1861, two sibling species of Hippopotamyrus ansorgii (Boulenger, 1905) one of which is yet undescribed (Kramer 1996, Van der Bank \& Kramer 1996), and male M. macrolepidotus (Kramer 1996, Kramer 1997a,b). Strong competition in the spectral low-frequency range must have acted as a selection pressure for a few species, $P$. catostoma among them, to shorten their EOD duration (that is, displaying an EOD in the high-frequency spectral range). This requires the evolution of exceptionally brief action potentials in electrocytes (that develop from muscle cells) which are not understood at present (reviews in Bennett 1971, Zimmermann 1985, 1993, Bass 1986), and a 'standard' nerve action potential is of long duration in comparison with the triphasic EOD of $P$. catostoma. (2) The South African $P$. wesselsi shares its habitat with one other mormyrid, $M$. macrolepidotus; the local variety of this species displays a biphasic (simpler) EOD waveform of a more low-frequency amplitude spectrum (Skelton et al. unpublished). Therefore, directional selection for an EOD much shorter than a nerve action potential was conceivably relaxed, and EOD duration increased to an average of $943 \mu$ s (versus $437 \mu$ s in the Upper Zambezi P. catostoma). Regressive evolution is well-known in cases where selection for a trait has been removed; in the present case, the relaxation of selection for brief EOD would have brought about regression to a more 'normal' (longer) duration of an EOD.

Would the Upper Zambezi and the South African forms of churchill discriminate between their EODs? Discrimination experiments have been performed with the West African mormyrid Pollimyrus adspersus. This species displays a triphasic EOD waveform resembling that of P. catostoma (Upper Zambezi, Figures $4 \mathrm{e}-\mathrm{h}$ ) except of being of much shorter duration. P. adspersus discriminates its own species' EOD from that of Gnathonemus petersii and detects the fine variation between conspecific individuals' EOD waveforms (Graff \& Kramer 1992). In playbacks of a synthetic discharge, $P$. adspersus even notices a phase shift of the $\mathrm{N}$-phase relative to the P1-phase of only $2 \mu$ s (Paintner 1998). Therefore, it is highly likely that specimens of the Upper Zambezi and the Sabie would discriminate between their vastly more dissimilar discharges, if confronted with one another. We conclude that, independently of each other, behaviour, genetics and morphology data all support the recognition of a new species of Petrocephalus for South Africa.

\section{Acknowledgements}

We acknowledge the South African and Namibian government authorities for permits, P.H. Skelton and M.N. Bruton, J.L.B. Smith Institute of Ichthyology, Grahamstown, for their hospitality and efficient help in numerous ways, A. Deacon and P. Kotze (Kruger National Park), as well as G. Wagner (Katima Mulilo), for acting as generous hosts and making available base camps, as well as their efficient help during the collecting of fish. We wish to thank D. van der Bank, A. de Castro (Auckland Park) and Birgit Kramer who helped during collection efforts. J. Engelbrecht (Mpumalanga Parks Board) gave permission and helped collecting specimens from the Limpopo system and the Pongola River, as well as W. Vlok (University of the North, South Africa) and F. Roux (Mpumalanga Parks Board). For the anatomical measurements we thank I. Kaunzinger, and for the gonad histology, B. Otto. For the photograph of the holotype we thank M. Müller and F. Glaw of the Zoologische Staatssammlung, Munich; for the map of Figure 3, K. Heine (Geography Department, University of Regensburg). We owe great thanks to R. Watson for critically reading and substantially improving the manuscript. A. Gill and J. MacLaine of The Natural History Museum, London, kindly gave access to the type material of $P$. catostoma and P. stuhlmanni. We were supported by travel grants and funding by Deutsche Forschungsgemeinschaft (grants SFB4/H1, Kr 446/10-1 and $\mathrm{Kr}$ 446/10-2 to BK). Animals were cared for in accordance with the principles and guidelines of the Canadian Council on Animal Care.

\section{References cited}

Barnard, K.H. 1948. Report on a collection of fishes from the Okavango River, with notes on Zambesi fishes. Annals of the South African Museum 36: 407-458.

Bass, A.H. 1986. Electric organs revisited: evolution of a vertebrate communication and orientation organ. pp. 13-70. In: T.H. Bullock \& W. Heiligenberg (ed.) Electroreception, John Wiley, New York.

Bastian, J. 1990. Electroreception. pp. 35-89. In: W.C. Stebbins \& M.H. Berkeley (ed.) Comparative Perception, vol. 2: Complex Signals, John Wiley, New York.

Bastian J. 1994. Electrosensory organisms. Physics Today, February 1994: 30-37.

Bell, C.C., J. Bradbury \& C.J. Russell. 1976. The electric organ of a mormyrid as a current and voltage source. J. Comp. Physiol. A 110: $65-88$ 
Bell-Cross, G. \& J.L. Minshull. 1988. The fishes of Zimbabwe. National Museums and Monuments of Zimbabwe, Harare. 294 pp.

Bennett, M.V.L. 1971. Electric organs. pp. 347-491. In: W.S. Hoar \& D.J. Randall (ed.) Fish Physiology, vol. 5, Academic Press, London.

Blache, J. 1964. Les poissons du bassin du Tchad et du bassin adjacent du Mayo Kebbi. Etude systématique et biologique. ORSTOM, Paris. 483 pp.

Blake, B.F. 1977. Aspects of the reproductive biology of Hippopotamyrus pictus from lake Kainji, with notes on four other mormyrid species. J. Fish Biol. 11: 437-445.

Boulenger, G.A. 1909. Catalogue of the fresh-water fishes of Africa in the British Museum (Natural History). British Museum (NH), London. 373 pp.

Bratton, B.O. \& B. Kramer. 1988. Intraspecific variability of the pulse-type discharges of the African electric fishes, Pollimyrus isidori and Petrocephalus bovei (Mormyridae, Teleostei), and their dependence on water conductivity. Exp. Biol. 47: 227-238.

Bratton, B.O. \& B. Kramer. 1989. Patterns of the electric organ discharge during courtship and spawning in the mormyrid Pollimyrus isidori. Behav. Ecol. Sociobiol. 24: 349-368.

Crawford, J.D. 1991. Sex recognition by electric cues in a soundproducing mormyrid fish, Pollimyrus isidori. Brain, Behav. Evol. 38: 20-38.

Gilchrist, J.D.F. \& W.W. Thompson. 1913. The freshwater fishes of South Africa. Annals of the South African Museum 11(5): 321-463.

Gilchrist, J.D.F. \& W.W. Thompson. 1917. The freshwater fishes of South Africa. Annals of the South African Museum 11(6): 465-579.

Gosse, J.-P. 1984. Mormyriformes. pp. 63-124. In: J. Daget, J.-P. Gosse \& D.F.E. Thys van den Audenaerde (ed.) Check-List of the Freshwater Fishes of Africa, ORSTOM/MRAC, Bondy (France)/Tervuren.

Graff, C. \& B. Kramer. 1992. Trained weakly-electric fishes Pollimyrus isidori and Gnathonemus petersii (Mormyridae, Teleostei) discriminate between waveforms of electric pulse discharges. Ethology 90: 279-292.

Günther, A. 1866. Catalogue of the fishes of the British Museum, vol. 6: Physostomi. London. $368 \mathrm{pp}$

Jubb, R.A. 1958. A preliminary report on the collections of freshwater fishes made by the Bernard Carp expeditions to the Caprivi Strip, 1949, the lower Sabi River, 1950, and to Barotseland, 1952. Occasional Papers of the National Museums of Southern Rhodesia 3: 177-189.

Kocher, T.D. \& C.A. Stepien. 1997. Molecular systematics of fishes. Academic Press, San Diego. 520 pp.

Kolding, J., E.M. Tirasin \& L. Karenge. 1992. Growth, mortality, maturity and length-weight parameters of fishes in Lake Kariba, Africa. NAGA, The ICLARM Quarterly 15: 39-41.

Kramer, B. 1990. Electrocommunication in teleost fishes: behavior and experiments. Springer-Verlag, Berlin. 240 pp.

Kramer, B. 1994. Communication behavior and sensory mechanisms in weakly electric fishes. pp. 233-270. In: P.J.B. Slater J.S. Rosenblatt, C.T. Snowdon \& M. Milinski (ed.) Advances in the Study of Behavior (vol. 23), Academic Press, San Diego
Kramer, B. 1996. Electroreception and communication in fishes. Gustav Fischer Verlag, Stuttgart. 119 pp.

Kramer, B. 1997a. A field study of African elephantfish (Mormyridae, Teleostei): electric organ discharges in Marcusenius macrolepidotus (Peters, 1852) and Petrocephalus catostoma (Günther, 1866) as related to sex. J. Afr. Zool. 111. 313-341.

Kramer, B. 1997b. Electric organ discharges and their relation to sex in mormyrid fishes. Naturwissenschaften 84: 119-121.

Kramer, B. \& B. Kuhn. 1993. Electric signaling and impedance matching in a variable environment: the electric organ of a mormyrid fish actively adapts to changes in water conductivity. Naturwissenschaften 80: 43-46.

Kramer, B. \& G.W.M. Westby. 1985. No sex difference in the waveform of the pulse type electric fish, Gnathonemus petersii (Mormyridae). Experientia 41: 1530-1531.

Ladiges, W. 1964. Beiträge zur Zoogeographie und Ökologie der Süßwasserfische Angolas. Mitteilungen des Hamburgischen Zoologischen Museums und Instituts 61: 221-272.

Leviton, A.E., R.H. Gibbs, Jr., E. Heal \& C.E. Dawson. 1985. Standards in herpetology and ichthyology: Part I. Standard symbolic codes for institutional resource collections in herpetology and ichthyology. Copeia 1985: 802-832.

Lévêque, C. \& D. Paugy. 1984. Guide des poissons d'eau douce de la zone du programme de lutte contre l'onchocercose en Afrique de l'Ouest. Convention ORSTOM-OMS, Paris. 392 pp.

Marcusen, J. 1854. Vorläufige Mittheilung aus einer Abhandlung über die Familie der Mormyren. Bulletin de la Classe PhysicoMathématique de l'Académie Impériale des Sciences de SaintPétersbourg 12: 2-14.

McEvey, S.F. (ed.) 1993. Evolution and the recognition concept of species. Collected writings of Hugh E.H. Paterson. Johns Hopkins University Press, Baltimore. 234 pp.

Moller, P. 1995. Electric fishes: history and behavior. Chapman \& Hall, London. 584 pp.

Nei, M. 1978. Estimation of average heterozygosity and genetic distance from a small number of individuals. Genetics 89 : 583-590.

Paintner, S. 1998. Elektrosensorische Grundlagen der Impulskurvenformanalyse für die Individualerkennung bei Pollimyrus adspersus (Mormyridae, Teleostei). Doctoral Dissertation, University of Regensburg, Regensburg. 88 pp.

Paterson, H.E.H. 1978. More evidence against speciation by reinforcement. S. Afr. J. Sci. 74: 369-371.

Paterson, H.E.H. 1988. On defining species in terms of sterility: problems and alternatives. Pac. Sci. 42: 65-71.

Pellegrin, J. 1936. Contribution à l'ichthyologie de l'Angola. Arquivos do Museu Bocage (Lisboa) 7: 45-62

Poll, M. 1967. Contribution à la faune ichthyologique de l'Angola. Publicações Culturais No. 75. Companhia de Diamantes de Angola (Diamang), Lisboa. 381 pp.

Ribbink, A.J. 1994. Alternative perspectives on some controversial aspects of cichlid fish speciation. Archiv für Hydrobiologie/Beiheft: Ergebnisse der Limnologie 44: 101-125.

Romeis, B. 1989. Mikroskopische Technik, 17th ed. Urban \& Schwarzenberg, München. 697 pp.

Sauvage, H.E. 1880. Etude sur la faune ichthyologique de l'Ogôoué. Archives du Muséum national d'Histoire naturelle (Paris) 2nd series(3): 5-56. 
Skelton, P.H. 1993. A complete guide to the freshwater fishes of southern Africa. Southern Book Publishers, Halfway House. $388 \mathrm{pp}$.

Skelton, P.H. 1994. Diversity and distribution of freshwater fishes in east and southern Africa. Annales Musée Royal de l'Afrique Centrale, Sciences Zoologiques 275: 95-131.

Skelton, P.H, M.N. Bruton, G.S. Merron \& B.C.W. van der Waal, 1985. The fishes of the Okavango drainage system in Angola, South West Africa and Botswana: taxonomy and distribution. Ichthyological Bulletin of the J.L.B. Smith Institute of Ichthyology 50: 1-21.

Takashima, F. \& T. Hibiya. 1995. An atlas of fish histology. Normal and pathological features. Gustav Fischer Verlag, Stuttgart $195 \mathrm{pp}$.

Van der Bank, F.H. 1996. Inter- and intraspecific allozyme comparisons of mormyrids (Pisces, Mormyridae) from South Africa and Namibia, with reference to an undescribed species. Water SA 22: 285-290.
Van der Bank, F.H. \& B. Kramer. 1996. Phylogenetic relationships between eight African species of mormyriform fish (Teleostei, Osteichthyes): resolution of a cryptic species, and reinstatement of Cyphomyrus Myers, 1960. Biochem. Syst. Ecol. 24: 275-290.

Whitehead, P.J. \& P.H. Greenwood. 1959. Mormyrid fishes of the genus Petrocephalus in Eastern Africa, with a redescription of Petrocephalus gliroides (Vinc.). Rev. Zool. Afr. 60: 283-295.

Zimmermann, H. 1985. Die elektrischen Fische und die Neurobiologie: über die Bedeutung einer naturgeschichtlichen Kuriosität für die Entwicklung einer Wissenschaft. Funktionelle Biologie und Medizin 4: 156-172.

Zimmermann, H. 1993. Synaptic transmission. Cellular and molecular basis. Georg Thieme Verlag/Oxford University Press., Stuttgart/New York. 144 pp. 